\title{
EFEKTIVITAS RELAKSASI PROGRESIF TERHADAP PENURUNAN INTENSITAS NYERI PADA PASIEN POST SECTIO CAESAREA DI RSU SEMBIRING TAHUN 2020
}

\author{
PENY ARIANI ${ }^{1}$, MASTARY ${ }^{2}$ \\ INSTITUT KESEHATAN DELI HUSADA DELI TUA \\ JL. BESAR DELITUA NO 77 KEC. DELI TUA KAB. DELI SERDANG 20355 \\ e-mail : penyariani@gmail.com; ayimastary@gmail.com
}

DOI : https://doi.org/10.35451/jkk.v2i2.383

\begin{abstract}
World Health Organization (WHO) for almost 30 years the rate of births with caesarea section became $10 \%$ to $15 \%$ of the delivery process exist in developing countries. In Indonesia, the results of basic health research in 2013 showed births with a caesarean section of $15.3 \%$ of the sample of 20,591 surveyed from 33 provinces. Based on statistical data that researchers obtained from the Medical Record Room of the Sembiring General Hospital, the number of patients with sectio caesarea from January to September in 2019 totaled 1,600 patients. Nursing problems that often arise in post sectio caesarea cases are painful sensory and emotional experiences that arise due to actual tissue damage. The nurse's independent action to control the pain felt by the patient is to do pain management with nonpharmacological techniques, namely progressive relaxation. The purpose of this study was to determine the effectiveness of progressive relaxation on decreasing pain intensity in post sectio caesarea patients. This study used a quasi-experimental design method with a non equivalent control group design. The sampling technique was 32 respondents, 16 intervention groups and 16 control groups. This study used a T-Test. The results of this study indicate the P-value $(0.839)>a(0.05)$. The conclusion of this study is that there is no effectiveness of progressive relaxation on the decrease in pain intensity in post sectio caesarea patients in the hybrid room of Sembiring General Hospital. For further researchers to be able to have the same research the same but with different variables in order to get more varied and better results.
\end{abstract}

Keywords : Pain, Caesarean Sectio, Progressive Relaxation

\section{PENDAhuluan}

Sectio caesarea merupakan lahirnya janin melalui insisi di dinding abdomen (laparatomi) dan dinding uterus (histerektomi). Persalinan dengan sectio caesarea membutuhkan pengawasan yang baik, karena tanpa pengawasan yang baik akan berdampak buruk kepada ibu, oleh sebab itu pemeriksaan dan monitoring perlu dilakukan beberapa kali sampai tubuh ibu dinyatakan dalam kondisi membaik (Sihombing et al., 2017). Sectio caesarea merupakan prosedur operasi terbanyak yang dilakukan pada wanita di dunia, tindakan sectio caesarea terus meningkat karena berbagai sebab (Sholikhah Wahyu Subekti, 2018). 
Persalinan sectio caesarea terus meningkat di seluruh dunia, khususnya di Negara-negara yang berpenghasilan tinggi dan menengah, serta telah menjadi masalah kesehatan yang utama di masyarakat (Sihombing et al., 2017).

Menurut World Health Organization (WHO, 2014) Negara-negara yang berkembang yang memiliki angka persalinan seksio sesarea diantaranya adalah Amerika Latin (40,5\%), Australia (32\%), Europe (25\%), Afrika (25\%) dan Asia (19,2\%) (Putinah, dkk, 2017). Sedangkan pada tahun (WHO, 2015) selama hampir 30 tahun tingkat persalinan dengan sectio caesarea menjadi $10 \%$ sampai $15 \%$ dari proses persalinan yang ada di Negara-negara berkembang.

Menurut Riskesdas (2013)(BADAN PENELITIAN DAN PENGEMBANGAN KESEHATAN and KEMENTERIAN KESEHATAN RI, 2013), angka ibu melahirkan dengan cara sectio caesarea di Indonesia sebesar 9,8\% dengan proporsi tertinggi di DKI Jakarta $19,9 \%$ dan yang terendah di Sulawesi Tenggara 3,3\%. Tingkat persalinan sectio caesarea di Indonesia sudah melewati batas maksimal standar 5-15\%, tingkat persalinan sectio caesarea di Indonesia sebesar $15,3 \%$ sampel dari 20.591 ibu yang melahirkan dalam waktu 5 tahun terakhir yang di survey dari 33 provinsi. Dari meningkatnya tingkat persalinan sectio caesarea terdapat adanya faktor- faktor risiko ibu pada saat melahirkan atau pada saat operasi caesarea sadalah ketuban pecah dini 13,4\%, preeklamsia 5,49\%, pendarahan $5,14 \%$, kelainan letak janin 4,40\%, jalan lahir tertutup $4,25 \%$, dan ruptur 2,3\% (BADAN PENELITIAN DAN PENGEMBANGAN KESEHATAN and KEMENTERIAN KESEHATAN RI, 2013)
Hasil Riskesdas provinsi Sumatera Utara 2013 menunjukkan kelahiran bedah sesar sebesar $12,7 \%$ dengan proporsi tertinggi di Pemantang Siantar $31,5 \%$ dan yang terendah di Mandailing Natal 0,4\%. Secara umum pola persalinan sectio caesarea menurut karakteristik menunjukkan proporsi tertinggi pada kuintil indeks kepemilikan teratas $24,7 \%$, tempat tinggal di perkotaan $17,1 \%$, pekerjaan sebagai wiraswasta $24 \%$, pendidikan lulus PT $26 \%$, dan kelompok umur $\geq 35$ tahun $17,1 \%$.

Berdasarkan data statistik yang peneliti peroleh dari Ruang Rekam Medik Rumah Sakit Umum Sembiring, jumlah pasien dengan sectio caesarea dari bulan Januari sampai dengan Desember tahun 2018 berjumlah 2.131 pasien, sedangkan pada tahun 2019 bulan Januari terdata 160 pasien, Februari 123 pasien, Maret 122 pasien, April 187 pasien, Mei 181 pasien, Juni 222 pasien, Juli 201 pasien, Agustus 191 pasien dan September 213 pasien sehingga total sectio caesarea dari bulan Januari sampai dengan September tahun 2019 berjumlah 1.600 pasien (Rekam Medik RSU Sembiring, 2019).

Tindakan sectio casearea merupakan salah satu alternatif bagi sesorang wanita dalam memilih proses persalinan di samping itu adanya indkasi medis dan non medis, tindakan sectio caesarea akan memutuskan kontinuitas atau persambungan jaringan karena insisi yang akan mengeluarkan reseptor nyeri sehingga pasien akan merasakan nyeri terutama setelah efek anastesi habis (Lovina SM Machado, 2012).

Nyeri merupakan pengalaman sensori dan emosional tidak menyenangkan yang muncul akibat kerusakan jaringan aktual atau pontensial yang digambarkan sebagai kerusakan awitan yang tiba-tiba atau 
lambat dari intesitas ringan hingga berat dengan akhir yang dapat diantisipasi atau prediksi (Rivai, Koentjoro and Utarini, 2013). Persalinan sectio caesarea memiliki nyeri lebih tinggi sekitar 27,3\% dibandingkan dengan persalinan normal yang hanya sekitar $9 \%$. Rasa nyeri meningkat pada hari pertama post operasi sectio caesarea (Rini, 2018).

Tindakan yang dapat dilakukan untuk mengatasi rasa nyeri adalah dengan cara terapi farmakologi dan non-farmakologi. Tindakan terapi farmakologi yaitu dengan memberikan obat-obatan seperti dengan obat analgesik, analgesik non steroid (NSAID) sedangkan terapi tehnik nonfarmakologi untuk dapat mengurangi nyeri dapat diberikan tehnik relaksasi (A. et al., 2019).

Teknik relaksasi progresif adalah tehnik merelaksasikan otot dalam pada bagian tertentu atau seluruhnya melalui tehnik program terapi ketagangan otot, tehnik relaksasi otot dalam merupakan merupakan teknik relaksasi yang tidak membutuhkan imajinasi atau sugesti. Adapun tujuan dari relaksasi progresif adalah membantu pasien menurunkan nyeri tanpa farmakologi, memberikan dan meningkatkan pengalaman subjektif bahwa ketegangan fisiologis bisa direlaksasikan sehingga relaksasi akan menjadi kebiasaan berespon pada keadan-keadaan tertentu ketika otot ketegangan, menurunkan stress pada individu, relaksasi dalam dapat mencegah manifestasi psikologis maupun fisiologis yang diakibatkan stress (Rahmawati, Widjajanto and Astari, 2017).

Berdasarkan hasil penelitian Aprina, Yowanda and Sunarsih (2017), dari skala intensitas nyeri sebelum terapi relaksasi progresif didapatkan hasil mean 5.20 Dengan standar deviasi 0.834. Sedangkan skala intensitas nyeri sesudah terapi relaksasi progresif didapatkan hasil mean 3.60 dengan standar devisiasi 0.681 hasil uji statistik didapatkan nilai nilai $\rho$-value 0.000 ( $\rho$-value $0.000<a$ 0.05), maka dapat disimpulkan ada pengaruh rata-rata intensitas nyeri yang bermakna pada pasien post op BPH (Benigna Prostat Hyperplasia) yang sudah dilakukan tindakan teknik relaksasi progresif. Dari hasil penelitian tersebut merekomendasikan bahwa tehnik relaksasi otot progresif dapat dijadikan tindakan mandiri keperawatan non-farmakologi yang dilakukan perawat untuk menurunkan nyeri post operasi sectio caesarea.

Berdasarkan hasil penelitian Fitria and Ambarwati (2017), tentang Efektifitas Tehnik Relaksasi Progresif Terhadap Intensitas Nyeri Pasca Operasi Laparatomi di Ruang Mawar II RSUD Dr. Moewardi. Penelitian ini menggunakan Quasi eksperimental design, dari hasil perbandingan sebelum dan sesudah relaksasi progresif dinyatakan signifikan (thitung $=$ $6,481>$ t tabel $=2,145$ atau $p=0,000<$ $0,05)$. Dengan adanya relaksasi progresif terjadi penurunan skala nyeri rata-rata sebesar 2 skala nyeri.

\section{METODE PENELITIAN}

Jenis penelitian yang digunakan dalam penelitian ini adalah quasi experiment design, dengan rancangan penelitian Non equivalent control group, penelitian ini menggunakan satu kelompok intervensi dan kelompok kontrol dengan cara dilakukan tes awal pretest (01) yang diberikan kepada dua kelompok, kemudian diberi intervensi $(X)$, setelah beberapa waktu kemudian peneliti melakukan tes akhir posttets (02) yang diberikan kepada dua kelompok.

Tempat dilakukan penelitian ini yaitu di ruang hibrida RSU Sembiring dan penelitian ini dilaksanakan pada bulan Februari 2020. Sampel yang 
digunakan dalam penelitian ini menggunakan tehnik Non-Random sampling dengan jenis Purposive sampling. Populasi dalam penelitian ini adalah pasien post sectio caesarea yang dirawat di ruang Hibrida RSU Sembiring Tahun 2020 yang memenuhi kriteria inklusi dan eksklusi. Jumlah sampel dalam penelitian ini masingmasing kelompok adalah 16 responden dengan menggunakan rumus federer.

Instrument penelitian yang digunakan dalam penelitian ini adalah menggunakan Relaksasi progresif serta lembar observasi yang berisi pengkajian nyeri pasien sebelum dan sesudah perlakuan baik pada kelompok kontrol atau kelompok intervensi. Instrument pengukuran tingkat nyeri menggunakan numeric rating scale (NRS). Penelitian ini menggunakan uji$\mathrm{T}$.

\section{HASIL}

\section{Karakteristik Responden}

Umur responden merupakan umur dalam tahun yang dihitung dari waktu kelahiran sampai tahun penelitian dilakukan. Berdasarkan Tabel 1 dapat diketahui bahwa dari 32 responden mayoritas berumur 31-35 Tahun sebanyak 14 orang $(43,8 \%)$ dan minoritas 36-40 Tahun tahun sebanyak 1 orang $(3,1 \%)$.

Tabel 1. Distribusi Frekuensi Karakteristik Responden Berdasarkan Umur Pada Pasien Nyeri Post Sectio Caesarea Di Ruang Hibrida RSU Sembiring Tahun 2020.

\begin{tabular}{cccc}
\hline No & Umur & $\mathbf{f}$ & $\mathbf{( \% )}$ \\
\hline 1 & $20-25$ Tahun & 8 & 25,0 \\
2 & $26-30$ Tahun & 9 & 28,1 \\
3 & $31-35$ Tahun & 14 & 43,8 \\
\hline 4 & $36-40$ Tahun & 1 & 3,1 \\
\hline & Total & $\mathbf{3 2}$ & $\mathbf{1 0 0}$ \\
\hline
\end{tabular}

Berdasarkan Tabel 2 dapat diketahui bahwa dari 32 responden mayoritas berpendidikan SMA sebanyak 13 orang $(40,6 \%)$ dan minoritas berpendidikan SD sebanyak 1 orang $(3,1 \%)$.

Tabel 2. Distribusi Frekuensi Karakteristik Responden Berdasarkan Pendidikan Terakhir Pasien Nyeri Post Sectio Caesarea Di Ruang Hibrida RSU Sembiring Tahun 2020.

\begin{tabular}{cccc}
\hline No & Pendidikan & $\mathbf{f}$ & $\mathbf{\%}$ \\
\hline 1 & SD & 1 & 3,1 \\
2 & SMP & 12 & 37,5 \\
3 & SMA & 13 & 40,6 \\
\hline 4 & D3/SI & 6 & 18,8 \\
\hline & Total & $\mathbf{3 2}$ & $\mathbf{1 0 0}$ \\
\hline
\end{tabular}

\section{Data Bivariat}

Berdasarkan tabel 3 diatas dengan menggunakan uji $T$ dependen pada pasien nyeri post sectio caesarea dapat disimpulkan pada kelompok intervensi pretest dan posttest dengan sampel 16 responden memiliki rata-rata (mean= $1,188)$, standar deviasi sebesar 0,981 sedangkan pada kelompok kontrol pretest dan posttest dengan sampel 16 responden memiliki rata-rata (mean= $1,188)$, standar deviasi sebesar 0,655 dengan $P$-value $(0,000)<$ a 0,05 maka $\mathrm{HO}$ ditolak Ha diterima yang artinya terdapat Pengaruh Pretest Dan Posttes Pada Kelompok Intervensi Dan Kontrol Terhadap Penurunan Intensitas Nyeri Pada Pasien Post Sectio Caesarea Di Ruang Hibrida RSU Sembiring Tahun 2020.

Tabel 3. Pengaruh Pretest Dan Posttes Pada Kelompok Intervensi Dan Kontrol Terhadap Penurunan Intensitas Nyeri Pada Pasien Post Sectio Caesarea Di Ruang Hibrida RSU Sembiring Tahun 2020

\begin{tabular}{clcccc}
\hline No Variab & el & mean & S.D & $\begin{array}{c}\text { P- } \\
\text { value }\end{array}$ \\
\hline 1 & $\begin{array}{l}\text { Pre-Post } \\
\text { Interve } \\
\text { nsi }\end{array}$ & 1,188 & 0,981 & 0,000 \\
\hline 2 & $\begin{array}{l}\text { Pre-Post } \\
\text { Kontrol }\end{array}$ & 16 & 1,188 & 0,655 & 0,000 \\
\hline
\end{tabular}

Berdasarkan Tabel .4 diatas dengan menggunakan uji $T$ independen dapat diketahui bahwa pada posttest 
kelompok intervensi terdapat 16 responden, miliki nilai rata-rata (mean=6,81), standar devisiasi 0,911, sedangkan pada posttest kelompok kontrol terdapat 16 responden memiliki nilai rata-rata (mean $=6,88)$, standar deviasi 0,806 dengan $P$-value 0,839 > a 0,05 HO diterima $\mathrm{Ha}$ ditolak yang artinya tidak terdapat Efektifitas Relaksasi Progresif Terhadap Penurunan Intensitas Nyeri Pada Pasien Post Sectio Caesarea Di Ruang Hibrida RSU Sembiring Tahun 2020.

Tabel 4. Efektifitas Relaksasi Progresif Terhadap Penurunan Intensitas Nyeri Pada Pasien Post Sectio Caesarea Di Ruang Hibrida RSU Sembiring Tahun 2020.

\begin{tabular}{lllll}
\hline $\begin{array}{c}\text { No Variab n } \\
\text { el }\end{array}$ & Mean & S.D & $\begin{array}{c}\text { P- } \\
\text { Value }\end{array}$ \\
\hline 1 & $\begin{array}{l}\text { Pre-Post } 16 \\
\text { Interve } \\
\text { nsi }\end{array}$ & 1,188 & 0,981 & 0,000 \\
\hline 2 & $\begin{array}{l}\text { Pre-Post 16 } \\
\text { Kontrol }\end{array}$ & 1,188 & 0,655 & 0,000 \\
\hline
\end{tabular}

\section{PEMBahasan}

Berdasarkan hasil analisis dengan menggunakan uji $T$ dependen pada pasien nyeri post sectio caesarea dapat disimpulkan pada kelompok intervensi pretest dan posttest dengan sampel 16 responden memiliki rata-rata (mean $=$ $1,188)$, standar deviasi sebesar 0,981 , dengan $P$-value $(0,000)<$ a 0,05 maka $\mathrm{HO}$ ditolak $\mathrm{Ha}$ diterima. Sedangkan pada kelompok kontrol pretest dan posttest dengan sampel 16 responden memiliki rata-rata (mean $=1,188)$, standar deviasi sebesar 0,655 dengan P-value $(0,000)<a \quad 0,05$ maka $\mathrm{HO}$ ditolak Ha diterima.

Rini (2018) mengatakan bahwa nyeri adalah sensasi yang tidak menyenangkan dan sangat individual yang tidak dapat dibagi dengan orang lain. Menurut McCafferi mendefinisikan nyeri sebagai segala hal yang dikatakan orang yang mengalami nyeri dan terjadi kapan saja orang tersebut mengatakan bahwa merasakan nyeri, dari dasar definisi ini adalah kemauan tenaga kesehatan untuk percaya bahwa klien mengalami nyeri dan orang yang berwenang terhadap nyeri tersebut (Astuti \& Merdekawati, 2016).

Fitria and Ambarwati (2017)Teknik relaksasi progresif adalah teknik merelaksasikan otot dalam pada bagian tubuh tertentu maupun seluruhnya melalui teknik program terapi ketegangan otot, dapat menurunkan nyeri tanpa farmakologi, memberikan dan meningkatkan pengalaman subjektif bahwa ketegangan fisiologis bisa direlaksasikan sehingga relaksasi akan menjadi kebiasaan pada keadaan ketika otot tegang (Aprina, Yowanda and Sunarsih, 2017).

Hasil penelitian ini sejalan dengan penelitian yang dilakukan oleh Maryati, Rokayah and Herawati (2020) dengan judul penelitian pengaruh teknik relaksasi progresif terhadap intensitas nyeri pada pasien post sectio caesarea di rumah sakit Palembang Bari Tahun 2017 dengan hasil uji statistik diperoleh $P$ value $=0,000<a=0,05$ sehingga dapat disimpulkan bahwa terdapat pengaruh pemberian relaksasi progresif terhadap intensitas nyeri pada pasien post sectio caesarea.

Menurut asumsi peneliti, penurunan tingkat nyeri sesudah diberikan relaksasi progresif pada pasien post sectio caesarea terjadi karena hormon endorphin yang telah distimulus setelah post sectio caesarea yang memiliki efek mengurangi nyeri. Hal ini didukung oleh Indriati and Setyani (2015), bahwa relaksasi progresif yang besrsifat sedatif terbukti efektif dalam mengurangi nyeri. Mekanisme relaksasi progresif dalam mengurangi nyeri sebagaimana dijelaskan teori gate kontrol, dimana implus nyeri akan berefek pada distraksi kognitif dalam 
inhibisi persepsi nyeri (Yusliana, Misrawati and Safri, 2015). Pada kelompok kontrol diberikan farmakologis 2 jam sebelum peneliti melakukan penelitian.

Berdasarkan hasil analisis dengan menggunakan uji $T$ independen dapat diketahui bahwa pada posttest kelompok intervensi terdapat 16 responden, miliki nilai rata-rata (mean $=6,81)$, standar devisiasi 0,911, sedangkan pada posttest kelompok kontrol terdapat 16 responden memiliki nilai rata-rata (mean $=6,88$ ), standar deviasi 0,806 dengan $\mathrm{P}$-value 0,839 > a 0,05 HO diterima Ha ditolak.

Hasil penelitian ini berbanding terbalik dengan teori Jacobson bahwa teknik relaksasi otot progresif digunakan untuk mengurangi atau mengatasi ketegangan serta memberikan rasa nyaman. Menurut Siregar and Rahman (2011), tindakan nonfarmakologi untuk mengatasi nyeri adalah dengan relaksasi otot progresif. Manfaat teknik relaksasi progresif meliputi: menurunkan ketegangan otot mengurangi tingkat kecemasan atau nyeri.

Menurut asumsi peneliti tidak adanya efektifitas relaksasi dalam penurunan intensitas nyeri pada pasien post sectio caesarea dikarenakan Pada hasil penelitian ini mengukur tingkat nyeri pretest dan postets yang dilakukan dengan teknik relaksasi progresif dapat menrunkan intesitas nyeri namun pada penelitian ini tidak terlalu signifikan penurunannya antara pretest dan posttest dikarenakan waktu penelitian hanya 1 hari, jika teknik relaksasi progresif di lakukan dengan tidak benar maka nyeri yang dirasakan sedikit berkurang namun masih terasa dan pasien merasa tidak nyaman dengan keadaannya, takut melakukan pergerakan karena takut merasa nyeri padahal pergerakan itu dapat mengurangi nyeri dan lebih rileks. Persepsi pasien terhadap nyeri tidak akan ada penurunan nyeri di karenakan pengetahuan yang kurang serta perilaku yang di tunjukkan tidak mendukung. Hal ini dapat mempengaruhi intensitas nyeri, karena jika teknik relaksasi progresif yang dilakukan secara berulang dan dengan tindakan yang benar dapat menurunkan rasa yang nyaman yang pada akhirnya akan meningkatkan toleransi persepsi dalam menurunkan rasa nyeri yang dialaminya, dan sebaliknya apabila tidak dilakukan dengan benar teknik relaksasi progresif nya menimbulkan rasa yang tidak nyaman dan pada akhirnya akan mengalami nyeri berat dan bahkan tidak ada penurunan nyeri (Maryati, Rokayah and Herawati, 2020). Selanjutnya jika seseorang mampu meningkatkan toleransinya terhadap nyeri maka seseorang akan mampu beradaptasi dengan nyeri, dan juga akan memiliki pertahanan nyeri yang lebih baik.

\section{KESIMPULAN}

Berdasarkan hasil penelitian tentang Efektifitas Relaksasi Progresif Terhadap Penurunan Nyeri Pada Pasien Post Sectio Caesarea Di Ruang Hibrida RSU Sembiring Tahun 2020, maka dapat disimpulkan beberapa hal sebagai berikut:

1. Tingkat nyeri pada pasien post sectio caesarea pada kelompok sesudah diberikan relaksasi progresif didapatkan hasil pada pretest memiliki nilai minimun 7 dan maximun 9 dengan rata-rata (mean $=8,00)$, sedangkan posttest relaksasi progresif memiliki nilai minimun 5 dan maximun 8 dengan rata-rata (mean $=6,81$ ).

2. Tingkat nyeri pada pasien post sectio caesarea pada kelompok kontrol kelompok kontrol didapatkan hasil pretest memiliki nilai minimun 7, maximun 9 dengan rata-rata $($ mean $=8,06)$, sedangkan 
hasil postetst memiliki nilai minimun 6 , maximun 8 dengan rata-rata (mean $=6,88)$.

3. Tidak ada efektifitas relaksasi progresif terhadap penurunan intensitas nyeri pada pasien post sectio caesarea di ruang hibrida tahun 2020 dengan nilai $(P-$ value $0,839>$ a 0,05 )

\section{DAFTAR PUSTAKA}

A., K. et al. (2019) 'Postoperative pain after cesarean section: assessment and management in a tertiary hospital in a low-income country', BMC health services research. BMC Health Services Research, 19(1), p. 68 . doi: 10.1186/s12913-019-3911-x LK http://vu.on.worldcat.org/atoztitle s/link?sid =EMBASE\&issn $=1472696$ 3\&id=doi: $10.1186 \% 2 F s 12913$ 019-3911-

x\&atitle $=$ Postoperative + pain + after +cesarean+section\%3A+assessme $\mathrm{nt}+$ and +management+in+a+tertia ry+hospital+in+a+low-

income + country\&stitle $=\mathrm{BMC}+$ Heal th + Serv + Res\&title $=\mathrm{BMC}+$ health $+\mathrm{s}$ ervices +research\&volume $=19 \&$ iss ue $=1 \&$ spage $=68 \&$ epage $=$ \&aulast $=$ Kintu\&aufirst $=$ Andrew\&auinit $=$ A.\& aufull $=$ Kintu $+A$. \&coden $=$ \&isbn $=\& p$ ages $=68$ -

\&date $=2019$ \&auinit1 $=$ A\&auinitm $=$.

Aprina, A., Yowanda, N. I. and Sunarsih, S. (2017) 'Relaksasi Progresif terhadap Intensitas Nyeri Post Operasi BPH (Benigna Prostat Hyperplasia)', Jurnal Kesehatan, $8(2)$, p. $289 . \quad$ doi: 10.26630/jk.v8i2.505.

BADAN PENELITIAN DAN PENGEMBANGAN KESEHATAN and KEMENTERIAN KESEHATAN RI (2013) 'Riskesdas 2013'. Available at:

http://www.depkes.go.id/resource s/download/general/Hasil

Riskesdas 2013.pdf.

Fitria, C. and Ambarwati, R. D. (2017) 'Efektifitas Tehnik Relaksasi Progresif Terhadap Intensitas Nyeri Pasca Operasi Laparatomi', Jurnal Keperawatan GSH, 4(2).
Indriati, P. and Setyani, V. A. (2015) 'PENGARUH TEKNIK RELAKSASI OTOT PROGRESIF TERHADAP PENURUNAN TINGKAT KECEMASAN PADA IBU INTRANATAL KALA I DI RS TELOGOREJO SEMARANG', ejournal.stikestelogorejo.ac.id.

Lovina SM Machado (2012) 'Cesarean Section in Morbidly Obese Parturients: Practical Implications and Complications', North American Journal Of Medical Science, 4(1), pp. 13-18. Available at: https://www.ncbi.nlm.nih.gov/pmc /articles/PMC3289484/.

Maryati, A. W., Rokayah, C. and Herawati, Y. (2020) 'PENGARUH PROGRESSIVE MUSCLE RELAXATION TERHADAP SKALA NYERI THE EFFECT OF PROGRESSIVE MUSCLE RELAXATION ON THE SCALE OF PAIN IN POST SECTIO CAESARIA', 3(1), pp. 59-64.

Rahmawati, P. M., Widjajanto, E. and Astari, A. M. (2017) 'the Influence of Progressive Muscle Relaxation on Anxiety Level of Pre-Caesarean Section Mothers in Delivery Room', NurseLine Journal, 2(2), p. 117. doi: $10.19184 / \mathrm{nlj} . v 2 \mathrm{i} 2.5929$.

Rini, S. (2018) 'PENURUNAN NYERI PADA IBU POST SECTIO CAESARIA PASCA INTERVENSI BIOLOGIC NURTURING BABY LED FEEDING', MEDISAINS, 16(Agustus), p. 83. doi:

10.22069/jwfst.2018.15021.1747.

Rivai, F., Koentjoro, T. and Utarini, A. (2013) 'Determinan Infeksi Luka Operasi Pascabedah Sesar', Kesmas: National Public Health Journal, 8(5), p. 235. doi: 10.21109/kesmas.v8i5.390.

Sholikhah Wahyu Subekti (2018) 'Indikasi Persalinan Seksio Sesarea', Jurnal Biometrika dan Kependudukan, 7(1), pp. 11-19. Available at: https://ejournal.unair.ac.id/JBK/article/view /5380/pdf.

Sihombing, N. et al. (2017) 'DETERMINAN PERSALINAN SECTIO CAESAREA DI INDONESIA 
( ANALISIS LANJUT DATA

RISKESDAS $2013 \quad$ ) The

Determinants of Sectio Caesarea Labor in Indonesia ( Further Analysis of Riskesdas 2013 ) PENDAHULUAN Setiap perempuan menginginkan persalinannya berjalan lanca', 8(1), pp. 63-75. doi:

10.22435/kespro.v8i1.6641.63-75.

Siregar, W. W. and Rahman, F. (2011) 'Pengaruh Penambahan Tehnik Relaksasi Progresif Pada Terapi Latihan Terhadap Penurunan Nyeri Post Sectio Caesarea'.

WHO (2014) Sectio Caesarea among Country, WHO. Available at: who.int.com.

Yusliana, A., Misrawati and Safri (2015) 'Efektivitas Relaksasi Benson Terhadap Penurunan Nyeri Pada Ibu Postpartum Sectio Caesarea', Jurnal Online Mahasiswa, 2(2), pp. 944-952. 